\title{
Defining Success in the Commons: Addressing Problem Orientations, Multidimensionality, Norms, and Tradeoffs
}

\author{
Allain J. Barnett ${ }^{1}$, Stefan Partelow ${ }^{2}$, Ulrich Frey ${ }^{3}$, Alejandro García-Lozano ${ }^{4}$, \\ Maria del Mar Mancha-Cisneros ${ }^{5}$, Christoph Oberlack ${ }^{6,7}$, Elicia Ratajczyk ${ }^{8}$, \\ Hillary Smith ${ }^{4}$, Sergio Villamayor-Tomás ${ }^{9}$ and Charlotte K. Whitney ${ }^{10}$ \\ School of International and Public Affairs, Florida International University, Miami, FL, US \\ 2 Leibniz Centre for Tropical Marine Research (ZMT), Bremen, DE \\ 3 Justus-Liebig-University, Giessen, DE \\ 4 Duke University Marine Laboratory, Beaufort, NC, US \\ Nicholas School of the Environment, Duke University, Durham, NC, US \\ 6 Institute of Geography, University of Bern, $\mathrm{CH}$ \\ Centre for Development and Environment (CDE), University of Bern, $\mathrm{CH}$ \\ 8 Institute for the Built Environment, Colorado State University, Fort Collins, CO, US \\ Instituto de Ciencia y Tecnología Ambientales (ICTA-UAB), Barcelona, ES \\ 10 School of Environmental Studies, University of Victoria, Victoria, BC, CA \\ Corresponding author: Stefan Partelow (stefan.partelow@leibniz-zmt.de)
}

Commons and social-ecological systems research examines institutional arrangements for governing natural resources to improve social and ecological outcomes. However, no universal definition of success exists. We examine the CPR and SES synthesis literature to identify trends, gaps and challenges for examining success. We address: (1) gaps in the literature, (2) multidimensionality and tradeoffs, and (3) and the link between problem orientation and definitions of success. To do this we conduct a comprehensive review of Large- $N$ studies, metaanalyses and systematic reviews of CPR and SES governance $(n=45)$. We found seven dimensions of success, corresponding to collective choice, constitutional and operational levels, temporal dimensions, and socio-economic outcomes. Most studies did not address power and tradeoffs, or specify the social groups to whom success would apply. The majority of studies defined success in one dimension, most often demand-side provisioning (e.g., productivity or biodiversity). A regression analysis suggests that studies on rangelands or grasslands, correlative studies, and/or studies of state property systems (i.e., protected areas) were more likely to use fewer dimensions of success. Problem orientations often did not correlate with dimensions of success considered in a study, suggesting that measures of success often cannot adequately address the full suite of problems recognized in synthesis research. This presents a significant challenge for collective action among scholars who aim to develop general knowledge on SES and CPR governance. We discuss exemplary studies that measure success as multidimensional, address power and tradeoffs, and conclude with four recommendations for advancing the analysis of success.

Keywords: Problem framing; power; collective action; success; norms; tradeoffs; multi-dimensionality

\subsection{Introduction}

Commons scholarship aims to examine what institutional arrangements for governing the commons can improve social and ecological outcomes (Ostrom 1990; Anderies and Janssen 2016). However, there is no single or agreed upon definition of successful outcomes, either social or ecological. What is viewed as successful in one case may not hold for another, or for different actors within the same case (Ostrom 2007; Agrawal and Benson 2011). Similarly, trade-offs between social and ecological success may occur, and the 
meaning of success will vary depending on temporal and spatial scales, as well as organizational levels (Persha et al. 2011; Poteete 2012; De Moor et al. 2016). While increasing amounts of rigorous commons research continue to be done, pausing to reflect on the current state of measuring and defining success is needed to identify potential gaps, challenges and directions forward to better understand what success is, and what it means for commons scholarship.

The purpose of this paper is to examine how success has been defined and evaluated in synthesis socialecological systems (SES) and common-pool resource (CPR) research. In recent years, researchers have turned to meta-analyses and large-N studies to synthesize lessons from diverse case studies to inform CPR and SES theory. This study provides a comprehensive review, the first to our knowledge, of how SES and CPR metaanalysis and large-N synthesis studies frame governance problems and define successful interventions.

Examining how success and concomitant problems have been framed and defined can inform efforts to compare and learn from multiple case studies, as well as to understand the context of successful interventions. Clarity in problem framing and definitions of success can help scholars and policy-makers address specific problems and avoid the trap of panaceas. Policy interventions should reflect the framing and assumptions that inform how outcomes are evaluated. More clearly defining and evaluating policy success will allow commons scholars to better contribute to improving governance systems, both practically and theoretically. Defining success also contributes to elucidating issues of power and tradeoffs in CPR cases, and enables transparency in decision-making. Overall, framing and defining what we consider success can help to mitigate conflict among CPR users, managers, NGOs, and other private sector actors.

In this study, we explicitly examine the various dimensions of success used in CPR and SES literature. Specifically, we address three key themes: (1) gaps in the literature, (2) multidimensionality, and (3) problem orientations of success in CPR studies. First, we ask: what dimensions of success are often missing in this synthesis literature? Synthesis studies might fail to explicitly consider the specific social groups to which 'success' applies, or the power dynamics involved in governing CPRs and SESs. Our second research theme asks the following questions: What dimensions of success are presented in the literature? Are tradeoffs among dimensions addressed? What types of studies are more likely to examine multiple dimensions of success? Lastly, our third research theme reflects the importance of understanding how problems are framed and defined, which inevitably influences the kinds of solutions or arrangements perceived as successful. We ask the following questions: What types of problem orientations do these studies have? Do problem orientations correspond with definitions of success? We review gaps, definitions of success, and problem orientations in medium to large- $\mathrm{N}$ analyses, meta-analyses, and systematic reviews (hereafter referred to as synthesis studies). We focus on these types of studies because they are influential in the literature (e.g., Cox et al. 2010; Gutierrez et al 2011; Pollnac et al. 2010), and they provide statistically and theoretically significant results and recommendations for scholars and policy-makers.

\subsection{Multidimensionality, problem orientations, and norms}

In the field of CPR and SES research, synthesis studies play a unique role in attempting to bring together empirical data across existing studies to identify common variables associated with successful governance. They attempt to capture patterns in the relationships between social contexts (e.g., property regime, configuration of rules, or household indicators) and biophysical characteristics (e.g., species richness, forest condition, fish abundance), often using outcome variables to interpret the success of particular governance arrangements or institutions. However, individual studies considered within synthesis studies do not necessarily measure the same independent and dependent variables and concepts (Frey 2017). Thus, the conclusions they draw are likely to vary depending on the definition of success.

More generally, synthesis assessments of success must inevitably reduce complex systems to a few measurable or aggregate indicators of either ecological or social performance such as species richness, tree condition, catch per unit effort, income or rule compliance. Therefore, despite clear strengths, these forms of analysis might miss important dynamics, processes and conflicts along the way. For example, the majority of the conservation literature does not address feedbacks between social and environmental variables (Miller et al. 2012). Similarly, a recent systematic review found that the community forestry literature did not adequately address the links between population dynamics, market forces, biophysical characteristics and environmental and livelihood outcomes (Hajjar et al. 2016). This challenge reflects long-standing debates in the social sciences regarding the relative merits of quantitative, qualitative, inductive, and deductive methods for understanding social dynamics and outcomes (Poteete et al. 2010). Poteete et al. (2010) argue for a methodologically pluralist approach to examining CPR and SES challenges to promote diverse theoretical approaches and to alleviate methodological debates. This pluralism can be enhanced through insights from grounded theory, which emphasizes generating theory inductively, and systematically and 
iteratively refining theory and concepts in relation to empirical data (Glaser and Strauss 2006). We generally support this pluralist approach by demonstrating the limitations in many synthesis studies in defining the construct of success, and by reviewing recent qualitative approaches that can enhance our ability to examine success as multidimensional and open to diverse problems and power dynamics.

Successful CPR governance can be attributed to original exemplars, such as Hardin's (1968) "tragedy of freedom in the commons," or Ostrom's (1990 p. 27) response, positing the potential for "individuals to use and govern CPRs". Specifically, Ostrom $(1990,29)$ defined successful CPR institutions as those "that enable individuals to achieve productive outcomes in situations where temptations to free-ride and shirk are ever present." Scholars have expanded on discussions of successful governance, interrogating what success might mean by exploring the intersections between CPR and SES governance and concepts such as justice, gender, livelihood security, knowledge, and power (Mansfield 2007; Brewer 2012; Barnett and Eakin 2015; Pinkerton and Davis 2015; Barnett et al. 2017). While these contributions have undoubtedly enriched our understanding of governing CPRs and SESs, they have also drawn greater attention to the many challenges in defining success.

The first challenge relates to multi-dimensionality. Since studies often reduce complex and multidimensional outcomes to singular or few measures of success, important information about social-ecological processes and context can be lost. For example, the Northwest Connemara oyster case study (Steins and Edwards 1999) was used in meta-analyses conducted by both Cox et al. (2010) and Baggio et al. (2016). In both meta-analyses (Cox et al. 2010; Baggio et al. 2016), coders were compelled by predefined criteria set out in their codebooks to code this case as "unsuccessful." However, the original article argued that "[p]redefined distinctions between categories of 'successful' (e.g., cooperation) and 'unsuccessful' (e.g., free-riding) are of little help," because the use of these categories obscure more in-depth analysis of complex contingent processes (Steins and Edwards 1999, p. 551). Additionally, as Steins and Edwards's (1999) demonstrate, while the Connemara Shellfish Farming Cooperative discussed in this case study did not achieve its stated goal of rebuilding native oyster stocks, it successfully achieved the cooperative's "hidden objective," of maintaining boundaries to protect important fishing grounds from the expansion of aquaculture. The cooperative was thus a political success from the perspective of a fish harvester, but an ecological and collective-action failure from the perspective of case study analysts. This example suggests that unidimensional examinations of multidimensional outcomes can obscure the meaning and management implications of social-ecological phenomena. This is a salient difficultly in large synthesis studies. A trade-off exists between describing reality accurately in detail and drawing meaningful and generalizable lessons. This is not uniquely associated with synthesis methods per se, but is rather a problem of methodological consistency across individual case studies, with the need to link to general theoretical frameworks but also adapt data collection and analysis techniques to each case individually so to best understand them. (Cox 2008; Ostrom 2009). Methodological transparency and data sharing during publishing is an additional barrier for synthesis studies (Partelow 2018).

Multidimensionality is particularly problematic given that the social context can affect multiple dimensions of success, creating trade-offs between social and ecological goals (Klain et al. 2014; Oberlack et al. 2015; Nilsson et al. 2018). For example, Oberlack et al. (2015) demonstrated that the community-based forest governance system in Mawlyngbna, India, was robust in ecological and institutional terms, but it involved community inequality. Persha et al. (2011) found evidence for tradeoffs and synergies between improved subsistence livelihoods and tree species richness in forest systems. Where forest users participated in the rulemaking process, the likelihood of "joint wins" was enhanced. Understanding if, when and how trade-offs exist is an important dimension of defining success.

The second challenge relates to problem orientation or problem framing: What is the problem that needs to be 'successfully' overcome? The ways in which researchers frame and define the problems that need to be solved form the basis for delineating performance indicators and successful outcomes. These framings may be explicitly stated or inferred implicitly. For instance, if studies examine resource governance through the lens of appropriation or provisioning dilemmas, they might be likely to measure success through metrics of ecological and institutional robustness (rather than, e.g., justice) to explain why natural resource systems are overused or degrading (Ostrom et al. 1994). However, in-depth case studies demonstrate that problem orientations and framings are linked to normative and political foundations, where framings of the problems themselves can be highly contested (Leach et al. 2010; Eriksen et al. 2015; Barnett et al. 2017). The framing of a given policy problem or governance dilemma reflects particular understandings of the kinds of intervention that are possible or favorable, and the kinds of actors responsible for bringing about solutions (Fischer 2003). Similarly, in sociological studies of science by actor-network theory (ANT) scholars, the formulation of problems (i.e., problematization) has been identified as a powerful means through which scientists influence the range of possible solutions and how they can position their expertise as central for 
resolving them (Callon et al. 1986). Therefore, analyzing problem orientations in CPR/SES studies is critical for understanding how success is evaluated, the implications, and what is absent in these formulations of success.

The third challenge is that measuring success is inherently normative (Moser and Boykoff 2013; Conley and Moote 2003), which reflects the researcher's perspective. What is interpreted as successful is likely to vary across case studies based on what local stakeholders prefer, and/or by the aims of researchers doing the analysis. Underlying choices about the definition of success in turn shape the selection of dependent variables and related indicators. What success is and how it is measured is often guided by disciplinary orientation, or increasingly, through transdisciplinary deliberations involving decision-makers, stakeholders and scientists (Schneider et al. 2019). Such deliberations can create 'target knowledge', i.e., knowledge about the values or goals to be achieved in a particular context (Hirsch Hadorn et al. 2008; Abson et al. 2014; Partelow and Winkler 2016). Further, to the extent that assessments of performance depend on input from resource users, stakeholders, managers, and experts, individual case studies can also reflect the values and norms elicited in individual case-study research.

\subsection{Methods}

This study was borne from discussions at a workshop titled "Breaking the Code: Synthesizing Coding Efforts for SES Research" held at the Socio-Environmental Synthesis Center (SESYNC), Maryland, USA, in July 2016. We address potential gaps in synthesis studies, categorize different dimensions of success and problem orientations, and examine the links between the two. We report on a systematic review of 45 meta-analysis and systematic review studies that examine the factors contributing to successful CPR and SES governance. While our results cannot directly address the normative foundations or perspectives of the researchers involved, we discuss the implied normative foundations to defining success emphasized in the literature, and those normative foundations that are less commonly expressed. We conclude by discussing exemplary studies addressing multidimensionality, and by listing recommendations for studying and conceptualizing success in CPRs and SESs.

\subsection{Study design and data collection}

We conducted a Scopus database search for peer-reviewed studies examining resource system types including fisheries, forestry, agriculture, irrigation, common-pool, natural resources, marine reserves, and SESs (See Appendix A1 for full search strings). These searches resulted in 1,246 results, which were then narrowed down based on the following criteria:

1. The study examined common-pool resource systems, natural resource management, or social-ecological systems

2. The analysis was based on a large-N, meta-analysis, systematic review, or comparisons of a medium to large number of case studies, here defined as more than 20 case studies. Though most syntheses included 40 or more case studies, the 20 case-study criteria allowed for the inclusion of studies using qualitative comparative analysis (e.g., Srinivasan et al. 2012).

3. The study either implicitly or explicitly addressed an outcome of interest related to success or similar evaluative statements, (e.g., bright spots, win-win)

The above criteria reduced the data set to 55 articles which was further refined to a final data set of 45 articles during the coding process as 10 articles were excluded upon further examination that did not fit the above criteria for our study (see Appendix A2 for list of articles).

\subsection{Coding}

A team of 11 coders developed two datasets. The first dataset consisted of descriptive questions about the studies, such as the temporal range of case studies included, geographic extent, whether the study addressed tradeoffs, resource systems and property systems included, and analysis methods. Coders filled in this dataset using a questionnaire and spreadsheet with a predefined set of responses, which was developed collaboratively and pilot tested on a sub-sample prior to implementation. Coder responses to questionnaires automatically updated a collaborative spreadsheet.

The second dataset consisted of qualitative themes coded from each study using collaborative spreadsheets. Coders entered direct quotations of problem orientations, definitions of success, and evaluative criteria for each article, which were later used for inductive coding. 
The qualitative themes were defined as follows:

1. Problem orientations: Statements made in the first few paragraphs (i.e., introduction) of an article indicating the primary challenge(s) to be addressed in the study, or in natural resource management practices. Problem orientations are related to commons dilemmas as highlighted in seminal commons literature (e.g., Ostrom 1990; Ostrom, Gardner, and Walker 1994), though some additional problem orientations are highlighted in the analysis below.

2. Definitions of success: More commonly associated with methods and results, definitions of success provide details regarding what outcomes are to be achieved for a case to be deemed successful. In some cases, success is defined in the introduction, especially in cases where success is measured using a binary coder evaluation. In some studies, the definition of success emerged from an inductive analysis of case studies.

3. Evaluative criteria: Methods used to determine the conditions under which success criteria were met (correlations, regressions, qualitative analysis, etc.).

While problem orientations and definitions of success are related concepts, there are important distinctions to highlight for the analysis that follows. A problem orientation focuses the reader's attention to specific interactions and dilemmas, and thus provides a frame within which conditions for success can be met. For example, while a fishing community may face various problems such as safety at sea, high unemployment, or high transaction costs in the buying and selling of fishing quotas and permits, a commons study may focus on the overexploitation of fisheries at sea, an appropriation dilemma, and potential demand-side provisioning dilemma (see Ostrom, Gardner and Walker 1994). It follows that success in the fishing community would be measured in terms of exploitation rates and measures of ecosystem health. Safety at sea, unemployment, and fishing quotas and permits would only be of interest to the analysis if they have hypothesized relationships with exploitation rates and measures of ecosystem health. By examining the relationship between problem orientations and definitions of success, we explore where attention is focused in the CPR and SES literature, and whether success measures adequately assess success in addressing the full suite of problems.

All coding steps were conducted by two coders for each paper. The independent coding was followed by documented discussions addressing any disagreements between coders. All remaining coding disagreements were resolved by the first author to ensure consistent interpretations.

After text segments relevant to problem orientations, definitions of success, and evaluative criteria were coded, the first author sub-coded each text segment. Text segments were sub-coded for the presence of different dimensions of problem orientations and definitions of success, and methodological approaches, the diversity of which resulted in a large number of codes. The number of codes was reduced by aggregating codes within categories, according to a modified typology developed by Ostrom $(1990,2005,2007)$ and Ostrom et al. (1994). We first categorized codes according to their relevance to challenges at different levels of institutional analysis (Ostrom 1990, 2005). The distinctions between these levels have been simplified for this analysis to reflect the data available in our coding. Collective choice and constitutional levels were combined in our analysis since studies often referred to management or participatory decision-making without specifying the applicable institutional levels. These levels refer to problems and successes related to processes affecting collective choice decision-making (constitutional), and the generation of operational rules (collective choice). Operational level problems orientations and definitions of successes relate to the interaction among individuals and their environments in light of internal and external incentives, and the operational rules influencing these interactions (Ostrom 2005). We further categorized codes that captured the benefits derived from interactions at the operational level (socio-economic benefits) and temporal dimensions (functional stability). In contrast to an operational level demand-side provisioning problem, in which current appropriation levels impact future appropriation potential, this time dimension captures the overall functioning of the CPR system or SES over time, and relates more closely to concepts such as resilience and adaptive capacity. An additional category was used to indicate studies using an inductive method to define success.

Within these categories, we further categorized codes according to commons dilemmas detailed in Ostrom et al. (1994) and the evaluative criteria highlighted in Ostrom (2005). Ostrom et al. (1994) describe dilemmas relating to appropriation, including appropriation externalities, assignment problems, and technological externalities, and dilemmas relating to provisioning, including demand and supply-side provisioning problems. While these distinctions between dilemmas and applicable forms of success would be beneficial, 
we found that problem orientations and definitions of success in the literature reviewed often did not reflect these distinctions. Thus, our coding categorized problem orientations and definitions of success related to appropriation, and demand-side provisioning. Ostrom (2005) provide helpful evaluative criteria for additional categories of problem orientations and definitions of success: economic efficiency, equity, adaptability, resilience and robustness, accountability, and conformance to general morality. We used these categories for guidance in the development of the problem orientations and dimensions of success for our analysis, with some modifications due to data constraints or a lack of specificity in the literature reviewed.

\subsection{Statistical analysis}

First, we examined gaps in the literature based on a summary and qualitative assessment of descriptive questions used to code case studies. We assess the degree to which aspects of power and definitions of social groups are addressed in CPR and SES synthesis studies. This more qualitative element of our analysis provides a basis for a discussion of studies that demonstrate the potential of incorporating multidimensionality, power, and well-defined social groups in their research.

Our second research question examines the multidimensionality of success. Once dimensions of success were categorized and described, we quantified the multidimensionality of success definitions in a given study as the sum of dimensions considered. Inductive measures of success were not included in this measure since inductive approaches elicited other substantive dimensions. This resulted in a maximum of 6 dimensions of success. We conducted an ordered logistic regression to examine factors influencing the number of dimensions of success. We examine three sets of factors influencing the number of dimensions of success; resource system types, methods used in the study, and property systems.

Our third research question examines problem orientations, and the relationship between problem orientations and definitions of success. We first examined the differences between frequency histograms of problem orientations and definitions of success. Second, we used a pairwise Spearman's rank correlation matrix to determine whether dimensions of success correlate with similar problem orientations. These correlations estimate the degree to which a study addresses the critical challenges set out in the initial framing of the article.

\subsection{Results}

\subsection{Background data and gaps in the literature}

The case study contexts of all meta-analyses are shown in Figure $\mathbf{1} \mathbf{a}$ and $\mathbf{1} \mathbf{b}$. The most common resource contexts studied were forestry and fisheries. Common property cases were the most frequently studied form of property rights followed by state and co-management arrangements. Of a total of 45 studies, $53.3 \%(n=27)$ analyzed a globally distributed cohort of cases, which we defined as representation of three or more continents. A similar number of studies $(\mathrm{n}=23)$ claimed that their results had global implications. The majority of studies $(\mathrm{n}=28)$ included specific property rights arrangements, such as state (e.g., protected areas), private (e.g., catch shares), and common property, as an explicit inclusion criterion for selecting their cases. Most studies used data individually collected from a literature search $(n=24)$, while some utilized

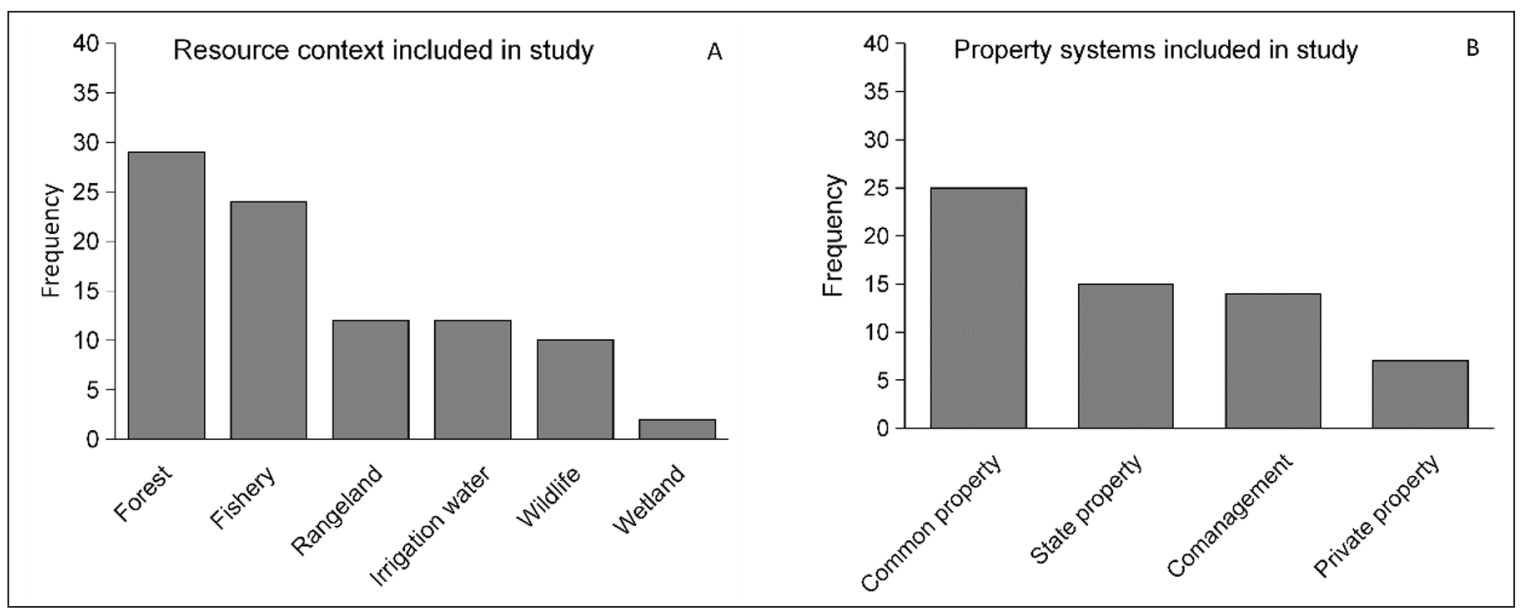

Figure 1: Frequency of case study contexts aggregated across all meta-analysis studies, including both (a) resource context and (b) property rights. 
data from existing databases such as the International Forestry Resources and Institutions (IFRI) database $(\mathrm{n}=13)$, a few collected empirical data $(\mathrm{n}=7)$, and 1 study used a combination of these approaches.

We found potential gaps in the literature for addressing power and social dynamics, as well as tradeoffs. Out of the 45 synthesis studies included in our analysis, few $(n=8)$ explicitly considered power dynamics as part of their analysis or discussion. A majority had implicit references to power $(n=20)$, such as mention of group inclusion, empowerment or participation, while the remaining 17 studies did not address power implicitly or explicitly. The 8 studies that address power dynamics did so in various ways, including individual measures or independent variables (2), overall discussions and problem orientations (2), the discussion of outcomes and conclusions (1), or in multiple sections of the article (3). Less than half of studies ( $\mathrm{n}=19)$ mentioned the actors or resource user groups to whom success would apply. Studies framed system interactions in different ways. Single direction linkages $(n=19)$ between independent and success variables (e.g., regressions) were common, along with unidirectional analysis that incorporated moderating or intermediate variables $(\mathrm{n}=18)$. All five studies that examined trade-offs considered two or more dimensions of success. Almost all studies examined case studies at a local level $(n=40)$, but only $40 \%$ made the geographic data or general locations $(n=18)$ for their cases available. Temporal data was available for $32(71.1 \%)$ case studies, usually in the form of a list of primary literature articles, including the date of publication.

\subsubsection{Dimensions of Success}

Our coding elicited 7 dimensions of success and one instance where success was defined inductively. These dimensions of success, their corresponding level of institutional analysis, definitions, and exemplary quotes from the literature examined are summarized in Table 1. The definitions column includes examples of specific codes aggregated into each dimension of success. The dimensions of success correspond well with those outlined by Ostrom (2005, p. 66-67), including outcomes such as 1) economic efficiency, 2) equity, and more process-related measures such as 3) adaptability, resilience and robustness, 4) accountability, and 5) conformance to general morality. However, we found several variations on these themes. Economic efficiency could be assessed from a resource use or resource user perspective. A measure of catch per unit effort (CPUE), for example, emphasizes the degree to which resource use has impacted the ability of others to use the resource. Economic efficiency measures from a resource user perspective examine the revenues, costs, and profits obtained from resource use. A higher CPUE indicates potentially higher revenues and lower costs of harvesting resources, but revenues and costs are not directly measured. Ostrom (2005, p. 66) also highlighted equity as an important outcome indicator, including "equality between individuals' contributions to an effort and the benefits they derive, and 2) on the basis of differential abilities to pay." Agrawal and Benson (2011, p. 201) defined equity outcomes as "equity of the allocation of benefits from the commons." Equity dimensions of success were considered in three of 45 studies and aggregated under the dimension of socio-economic benefits. Ostrom (2005) further considered adaptability, resilience, and robustness as criteria applicable to repeated situations requiring behavioral change over time. We categorized outcomes of institutional fit, adaptability, and resilience as functional stability measures. At the constitutional or collective choice levels, Ostrom (2005) proposed measures of accountability to assess whether the officials who develop policy and choose rules are accountable to those who are affected by them. The analyses reviewed in this study often used more general measures of the effectiveness of governance, or measures indicating the degree to which resource users participate, or are empowered to play a role in policy and rulemaking. It was unclear whether these dimensions of success consider outcomes at the constitutional or collective choice level of analysis. Finally, we found the dimensions of success that consider changes in behavior or attitudes corresponded to evaluations of general morality fostered by institutional arrangements (Ostrom 2005). These dimensions most often focused on trust, reciprocity, positive interactions or general acceptance of stewardship attitudes.

Another dimension of success often measured considered demand-side provisioning. This dimension of success corresponds with Ostrom et al. (1994) definition of provisioning problems in which appropriation impacts the productive capacity of the resource. In practice, it is often difficult to distinguish between measures of sustainable appropriation or use of resources, and demand-side provisioning problems. We categorized measures of ecosystem quality, biodiversity, productivity, or measures of resource collapse as demand-side provisioning problems. By contrast, the sustainable resource dimension is defined by outcomes that only refer to decreased use of resources, or improved use of resources with less impacts on other resource users. These dimensions are sometimes mentioned or measured together. For example, Brooks et al. (2012, p. 1) refer to both "decreased off-take" and "improved outcomes for the habitat or species of interest". 
Table 1: Definitions of dimensions of success and exemplary quotes.

\begin{tabular}{|c|c|c|c|}
\hline Level & Dimensions of success & Definition & Example \\
\hline \multirow[t]{2}{*}{$\begin{array}{l}\text { Constitutional or } \\
\text { collective choice }\end{array}$} & Participation or inclusion & $\begin{array}{l}\text { Participation, inclusion, } \\
\text { or empowering resource } \\
\text { users }\end{array}$ & $\begin{array}{l}\text { Provide fair participatory, } \\
\text { management, and access rights } \\
\text { (Pagdee et al. 2006; p. 43) }\end{array}$ \\
\hline & Effective management & $\begin{array}{l}\text { Effective management } \\
\text { or governance of natural } \\
\text { resource systems }\end{array}$ & $\begin{array}{l}\text {...I am applying a working } \\
\text { description of effective and } \\
\text { successful CBNRM organizations } \\
\text { as those organizations that } \\
\text { are making progress toward } \\
\text { increased efficiency and } \\
\text { effectiveness of natural resource } \\
\text { management (Gruber 2010) }\end{array}$ \\
\hline \multirow[t]{3}{*}{ Operational level } & Behavior or attitude change & $\begin{array}{l}\text { Behavioral outcomes, } \\
\text { such as trust, reciprocity, } \\
\text { positive interactions, or } \\
\text { stewardship }\end{array}$ & $\begin{array}{l}\text { Positive PA-community } \\
\text { relationship means PA staff } \\
\text { and the local community have } \\
\text { good contact and interaction; } \\
\text { they tolerate and relate well } \\
\text { whereas negative PA-community } \\
\text { relationship means PA staff and } \\
\text { the local community have no } \\
\text { interaction or no tolerance and } \\
\text { do not relate well (Mutanga et al. } \\
\text { 2015; p. 9) }\end{array}$ \\
\hline & Sustainable appropriation & $\begin{array}{l}\text { Sustainable appropriation } \\
\text { or use of resources }\end{array}$ & $\begin{array}{l}\text {...success reflects positive changes } \\
\text { in views of conservation goals, } \\
\text { decreased off-take, improved } \\
\text { outcomes for the habitat or } \\
\text { species of interest, and a variety } \\
\text { of livelihood benefits, respectively } \\
\text { (Brooks et al. 2012; p. 1) }\end{array}$ \\
\hline & Demand-side provisioning & $\begin{array}{l}\text { Resource quality, } \\
\text { condition, response, } \\
\text { productivity, diversity, or } \\
\text { collapse }\end{array}$ & $\begin{array}{l}\text {...the extent to which MPAs fulfil } \\
\text { their ecological potential, or } \\
\text { conservation value, characterized } \\
\text { as ecological response of fish } \\
\text { communities... (Edgar et al. 2014; } \\
\text { p. 216) }\end{array}$ \\
\hline Socio-economic & Socio-economic benefits & $\begin{array}{l}\text { Equity, economic } \\
\text { indicators, livelihoods or } \\
\text { social welfare }\end{array}$ & $\begin{array}{l}\text { We consider three outcomes: } \\
\text { livelihood contributions of } \\
\text { commons for users, sustainability } \\
\text { of the commons (ecological or } \\
\text { social/institutional), and equity } \\
\text { of the allocation of benefits } \\
\text { from the commons (Agrawal and } \\
\text { Benson 2011; p. 201) }\end{array}$ \\
\hline Temporal & Functional stability & $\begin{array}{l}\text { Resilience, institutional fit } \\
\text { and stability }\end{array}$ & $\begin{array}{l}\text { Ecological objectives: } \\
\text { condition of resource; stability, } \\
\text { sustainability; productivity, } \\
\text { resilience; biodiversity; avoiding } \\
\text { or halting environmental } \\
\text { degradation (Frey 2013; p. 5) }\end{array}$ \\
\hline Other & Inductive & $\begin{array}{l}\text { Definition inductively } \\
\text { determined }\end{array}$ & $\begin{array}{l}\text { Our query sought to take stock of } \\
\text { the successes and failures of ACM } \\
\text { by systematically analyzing all } 108 \\
\text { items (Plummer et al. 2012; p. 8) }\end{array}$ \\
\hline
\end{tabular}




\subsubsection{Types of Studies Examining Multiple Dimensions of Success}

The number of dimensions used to define success in a given study estimates the degree to which that study considers multiple dimensions of success. Of 45 studies, $47 \%(n=21)$ defined success in one dimension only, while $24.4 \%(\mathrm{n}=11)$ used two and $31.1 \%(\mathrm{n}=13)$ used 3 or more, including one study (Pagdee et al. 2006) which used 6 dimensions to define success (Figure 2). Studies using inductive success definition methods elicited 4 dimensions of success, on average, while non-inductive studies considered 1.9. This is particularly strong evidence that outcome measures of success are being simplified into single indicators, with few studies using three or more indicators. Of the 21 studies using single indicators, 14 used demandside provisioning.

We further examined the types of studies addressing multiple dimensions of success using ordered logistic regression. Since the vast majority of studies had one or two dimensions of success, we conducted the regression using the categories of one, two, and three or more dimensions of success. We used robust standard errors estimates to address misspecification errors. Results of the ordered logistic regressions are summarized in Table 2. The resource system model indicated that studies that examined irrigation and water resource systems were more likely to use more dimensions of success, while grassland or rangeland studies were more likely to use less. The methods model suggests that correlative (i.e., regressions, correlations and associations with outcomes) studies used fewer definitions of success.

Of the 45 studies included, 28 explicitly described the property systems considered, while 9 studies implied property systems without explicitly stating them, and 8 did not mention property systems as inclusion criteria. This challenged our efforts to accurately assess the property systems included in case study analyses. Despite these challenges, the results of the property systems model demonstrated that studies that focused on state property systems (such as protected areas) were more likely to consider fewer dimensions of success. Studies that implicitly or explicitly examined state property systems examined an average of 1.4 dimensions of success, while those that did not examined 2.57.

The overall model included significant factors found in the resource system, methods, and property model. This model indicates a negative relationship between the number of dimensions of success and grassland and/or rangeland studies, correlative analyses, and studies of state property systems. The positive relationship between dimensions of success and irrigation studies was not retained in the overall model.

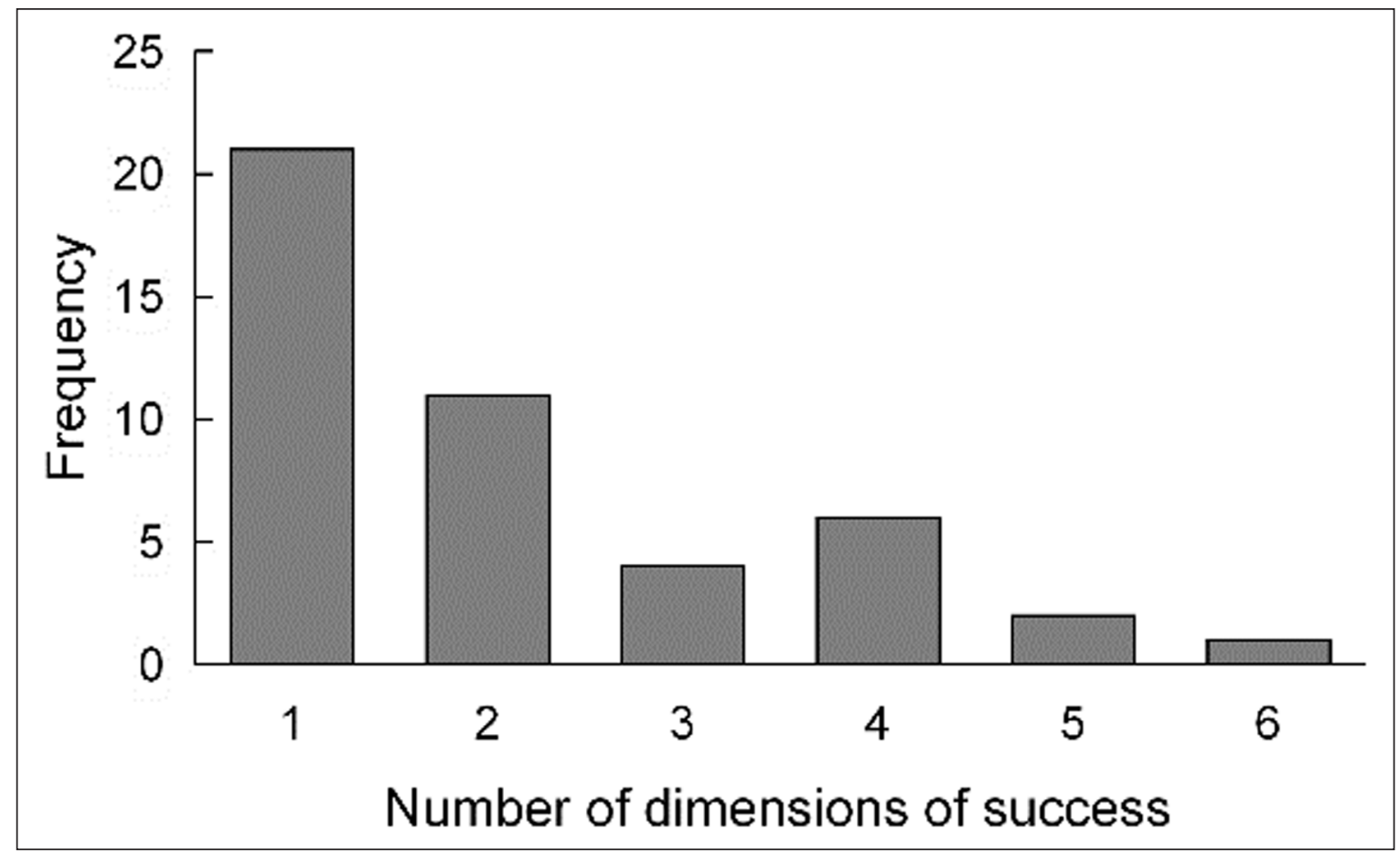

Figure 2: The number of success indicators used by large- $\mathrm{N}$, meta-analyses, and systematic reviews of socialecological systems and common pool resources. 


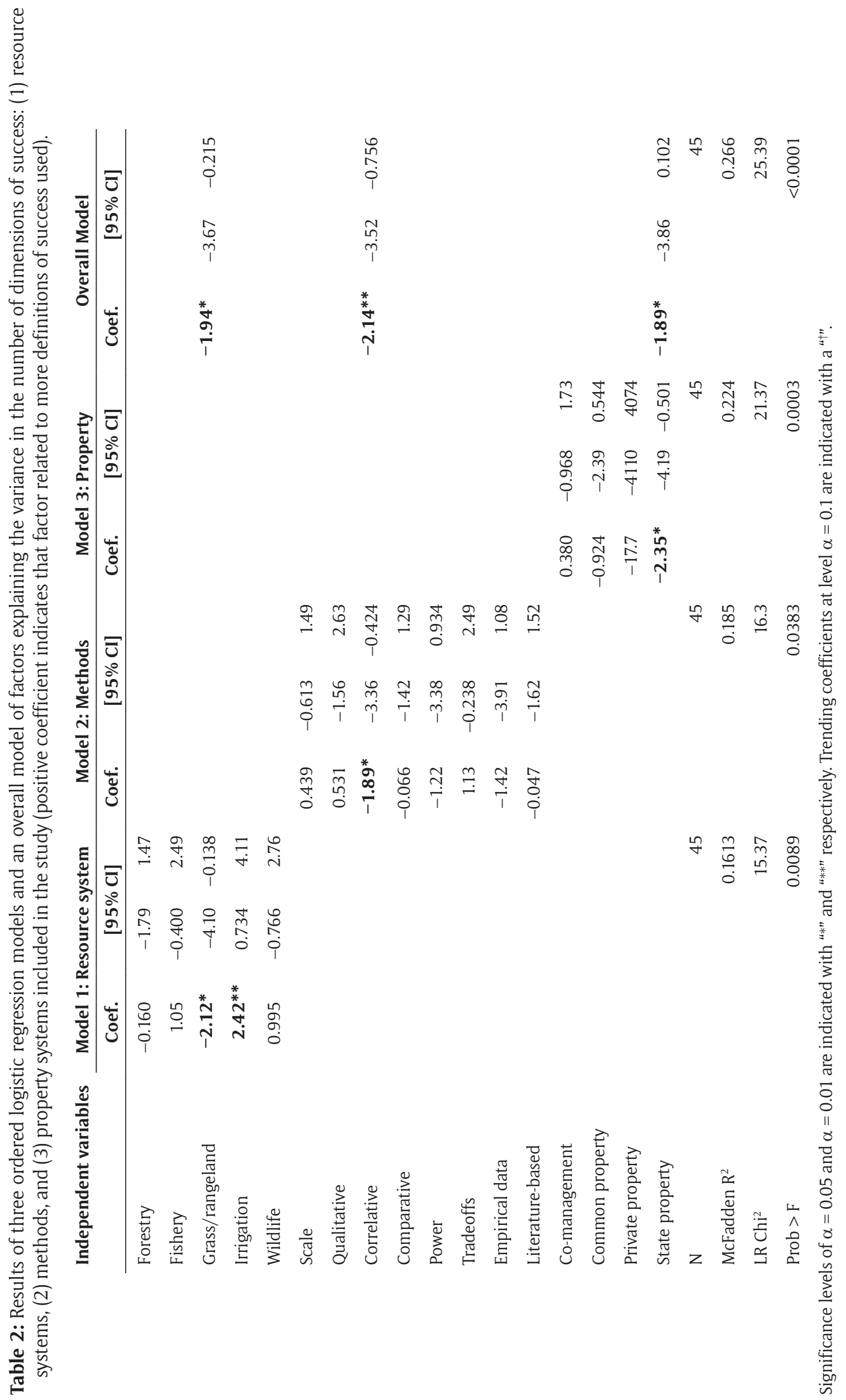




\subsection{Problem orientations}

As indicated in the definitions and examples in Table 3, six of eight problem orientations corresponded with definitions of success. For example, authors mentioned the need for participation and inclusive decisionmaking at the constitutional or collective choice level, which corresponds with definitions of success related to participation or community empowerment. Similarly, appropriation problems corresponded to sustainable appropriation. We found, however, some problem orientations that differed from dimensions of success. At the operational level, some studies pointed to lacking operational rules to incentivize sustainable resource use or behavioral change. This problem orientation, however, relates well to success in terms of behavioral and attitudinal changes, since operational rules influence behavioral outcomes.

Table 3: Definitions of problem orientations and exemplary quotes.

\begin{tabular}{|c|c|c|c|}
\hline Level & $\begin{array}{l}\text { Problem } \\
\text { orientation }\end{array}$ & Definition & Example \\
\hline \multirow[t]{2}{*}{$\begin{array}{l}\text { Constitutional or } \\
\text { collective choice }\end{array}$} & $\begin{array}{l}\text { Participation or } \\
\text { inclusion }\end{array}$ & $\begin{array}{l}\text { Co-management, inclusive } \\
\text { decision-making, participation, } \\
\text { and shared power arrangements }\end{array}$ & $\begin{array}{l}\text { Formalized local participation in } \\
\text { forest governance via decentralization } \\
\text { is often viewed as a key mechanism } \\
\text { to provide incentives to local } \\
\text { communities to use forests } \\
\text { sustainably (Persha et al. 2011; } \\
\text { p. 1606) }\end{array}$ \\
\hline & $\begin{array}{l}\text { Governance or } \\
\text { management }\end{array}$ & $\begin{array}{l}\text { Effectiveness of governance at } \\
\text { an unspecified level }\end{array}$ & $\begin{array}{l}\text { Understanding how forest commons } \\
\text { can be managed and governed better } \\
\text { is important...(Chhatre and Agrawal } \\
\text { 2009; p. 13286) }\end{array}$ \\
\hline \multirow[t]{4}{*}{ Operational level } & Operational rules & $\begin{array}{l}\text { An expressed need to address } \\
\text { specific challenges to specific } \\
\text { operational rules }\end{array}$ & $\begin{array}{l}\text { MPAs often fail to reach their full } \\
\text { potential as a consequence of factors } \\
\text { such as illegal harvesting, regulations } \\
\text { that legally allow detrimental } \\
\text { harvesting, or emigration of animals... } \\
\text { (Edgar et al. } 2014 \text { p. } 216 \text { ) }\end{array}$ \\
\hline & Appropriation & $\begin{array}{l}\text { Exploitation of the resource that } \\
\text { affects other users }\end{array}$ & $\begin{array}{l}\text {...many scholars interested in local } \\
\text { level sustainable outcomes either } \\
\text { assert or imply a positive relationship } \\
\text { between greater socio-economic } \\
\text { equality and more sustainable } \\
\text { resource use (Anderrson and Agrawal } \\
\text { 2011; p. 866) }\end{array}$ \\
\hline & $\begin{array}{l}\text { Demand-side } \\
\text { provisioning }\end{array}$ & $\begin{array}{l}\text { Extinction problems, biodiversity } \\
\text { loss, ecosystem services, or } \\
\text { degraded productive capacity }\end{array}$ & $\begin{array}{l}\text { Slowing tropical deforestation } \\
\text { and forest degradation remains an } \\
\text { enormous challenge at both national } \\
\text { and global scales... (Porter-Bolland et } \\
\text { al. 2011; p. 1) }\end{array}$ \\
\hline & Property rights & $\begin{array}{l}\text { Common property situations, } \\
\text { lack of private property rights, } \\
\text { open access }\end{array}$ & $\begin{array}{l}\text { Why are actively managed fisheries } \\
\text { systematically overexploited? ... } \\
\text { Because individuals lack secure rights } \\
\text { to part of the quota... (Costello et al. } \\
2008 \text { pp. 1678-1679) }\end{array}$ \\
\hline $\begin{array}{l}\text { Socio-economic } \\
\text { outcomes }\end{array}$ & $\begin{array}{l}\text { Socio-economic } \\
\text { benefits }\end{array}$ & $\begin{array}{l}\text { Reducing inequality, supporting } \\
\text { livelihoods, well-being and } \\
\text { economic development }\end{array}$ & $\begin{array}{l}\text {...some fisheries co-management } \\
\text { initiatives have improved both } \\
\text { ecosystems conditions, and the } \\
\text { livelihoods of resource users (MacNeil } \\
\text { and Cinner 2013; p. 1) }\end{array}$ \\
\hline Temporal & Functional stability & $\begin{array}{l}\text { Adapting to changing } \\
\text { conditions, and long-term } \\
\text { resilience }\end{array}$ & $\begin{array}{l}\text {... past models of success are being } \\
\text { confronted by unprecedented changes } \\
\text { due to globalization and climate } \\
\text { change. (Baggio et al. } 2016 \text { p. 3) }\end{array}$ \\
\hline
\end{tabular}


Additionally, some studies pointed to problems stemming from property rights, such as collective action challenges stemming from common property rights, or explicit statements problematizing a lack of private property rights. This result is not surprising, since the nature of property rights and boundaries are often proposed in the problematization of CPR and SES challenges, but property rights are rarely deemed successful outcomes in themselves.

Figure 3 shows the frequency of different problem orientations and definitions of success (not mutually exclusive) within the meta-analyses themselves. Some clear differences are evident. Appropriation problems were by far the most common, followed by socio-economic benefits, governance/management problems and demand-side provisioning problems. In contrast, demand-side provisioning was the most common dimension of success, followed by socio-economic benefits, effective management and sustainable use of resources. Figure $\mathbf{3}$ also demonstrates that studies often mention problems related to socio-economic benefits, governance, and participation/inclusion, but less often address these problems when measuring success. The difference between the frequencies of appropriation and demand-side provisioning themes likely stem from the close relationship between these problems and measures of success. Measures of ecosystem, habitat or resource conditions often serve as indicators that resources are being appropriated sustainably.

Problem orientations were rarely associated with dimensions of success, and half of associations were negative (Table 4). Studies that framed problems in terms of a lack of operational rules were less likely to examine socio-economic indicators of success, while studies focused on demand-side provisioning problems were less likely to examine dimensions of effective management and functional stability. Studies oriented towards socio-economic challenges were more likely to use inductive approaches to examine success, though it is important to note that only five studies used inductive approaches. Of the 45 studies, only 3 explicitly frame problems in terms of functional stability. Despite the small number of studies, we found a significant positive association between stability problems and dimensions of success that considered participation and inclusion and functional stability.

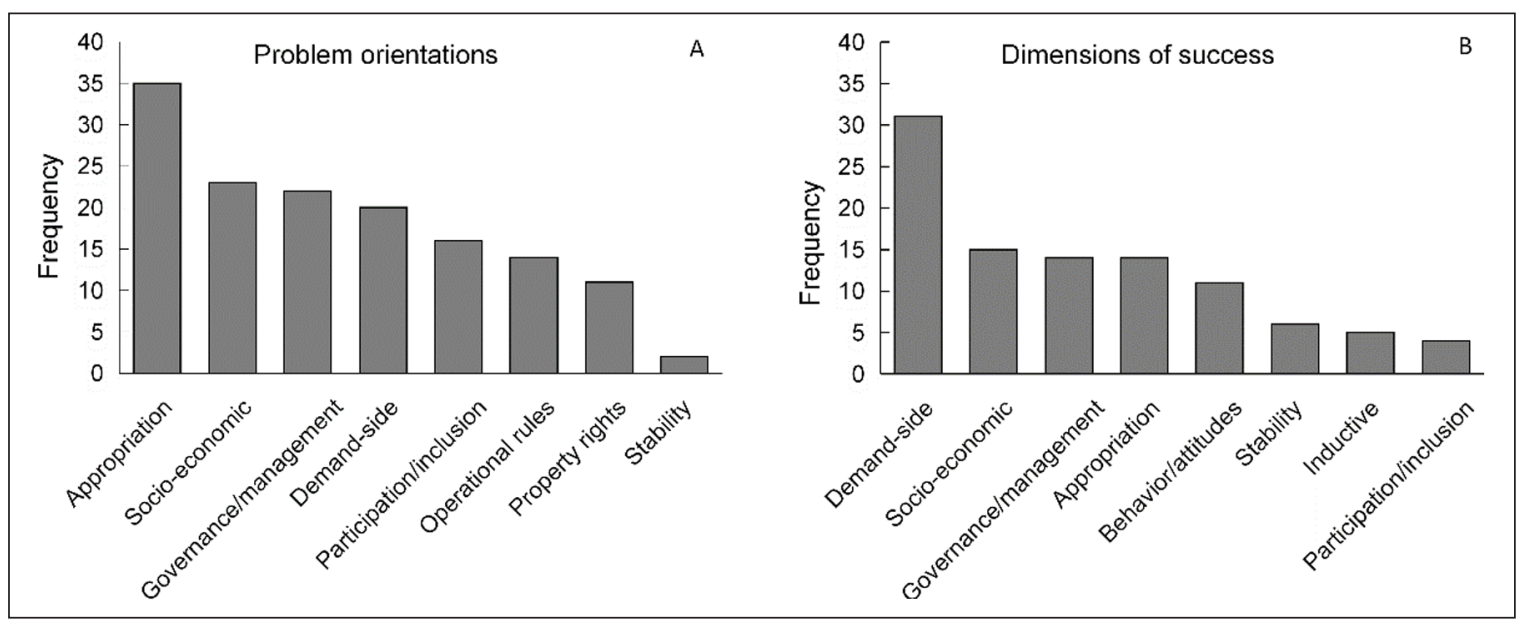

Figure 3: Frequency of a) problem orientations $\mathbf{b}$ ) and definitions of success aggregated across all studies. Note: the codes are defined in Table 1 and 3.

Table 4: Problem orientations and associated dimensions of success based on a Spearman's Rank correlation matrix.

\begin{tabular}{llrr} 
Problem orientation & Associated dimension of success & Spearman's $\boldsymbol{\rho}$ & $\boldsymbol{P}$-value \\
\hline Operational rules & Socio-economic benefits & -0.3989 & 0.0066 \\
Demand-side provisioning & Effective management & -0.373 & 0.0117 \\
& Functional stability & -0.351 & 0.0181 \\
Socio-economic benefits & Inductive definition of success & 0.346 & 0.0200 \\
Functional stability & Effective management & 0.419 & 0.0041 \\
& Functional stability & 0.419 & 0.0041
\end{tabular}




\subsection{Discussion \\ 4.1 Gaps in the literature}

Similar to other reviews of the literature (e.g., Miller et al. 2012; Hajjar et al. 2017) our analysis identified gaps and missing linkages in the CPR and SES literature. The majority of studies did not address tradeoffs between outcomes. Hajjar et al. (2017) found that the literature focused on environmental outcomes and relied on qualitative assessments of socioeconomic outcomes. We found a similar focus, and where authors addressed socio-economic problems, they were more likely to use inductive techniques to elicit success measures.

Very few studies explicitly considered power relationships. While studies often mention empowerment, participation, and inclusion, few examine the ways in which natural resource governance and management interventions can reconfigure the relationships between legitimized knowledge, claims to authority, and the subjectivities of resource users, managers, and other stakeholders (Agrawal 2005; Eriksen et al. 2015). Explicit examinations of power dynamics included indicators of public power exercised for private gain (Cinner et al. 2016), degree of devolution of power (Casse and Milhøj 2011), indicators of relative bargaining power and local influence over decision-making, monitoring, and operational rules (Maliao et al. 2009). Howe et al. (2014) analyzed case studies of the use of ecosystem services for human well-being with explicit attention to tradeoffs, synergies, and the dynamics that create winners and losers in management outcomes. Hirschnitz-Garbers and Stoll-Kleemann (2010) argue that protected areas outcomes should be assessed using indicators of biocultural diversity, participation and meaningful voice in decision-making, and indicators of class, education, income, ethnicity, and gender. Mwangi et al. (2012) analyze case studies with attention to the relative bargaining power of smallholders, and the conditions that contribute to elite capture of decentralized natural resource management regimes. These measures and approaches to power can further unpack the details of participatory process, and attributes of processes that help managers and resource users navigate tradeoffs and synergies in CPR and SES management.

Most often studies that considered social groups in their inclusion criteria used terms like resource users or communities, but few studies address the social and political construction of these groupings. This can be problematic given that some actors may be historically and systematically excluded from formal designations of who counts as a legitimate resource user (Smith and Basurto 2019). For example, few studies differentiate outcomes of success across gender, despite the recognition of their importance in CPR systems like small-scale fisheries (Smith and Basurto 2019; Meinzen-Dick et al. 2014). Gender also represents dimensions of power, which may be difficult to measure, but are nonetheless recognized as important outcomes associated with CPR and SES success (Epstein et al. 2014; Fabinyi et al. 2014; Boonstra 2016). These social group dynamics often intersect with collective or individual property rights, which can further influence the nature of exclusive or inclusive access to resources among social groups (Meinzen-Dick et al. 2014; Barnett et al. 2017; Brewer et al. 2012). Future research could benefit from integration with scholarship examining the relationships between the environment and race, ethnicity, gender, religion and other dimensions of human and social diversity (Ishiyama 2003; Hartberg et al. 2016; Baldwin 2017; Pulido 2017; De Lara 2018; Meinzen-Dick et al. 2014; Grove et al. 2020). Additionally, this research could explore the relationships between social group dynamics, private and collective property systems, and tradeoffs and inequities in outcomes for communities inside and outside clearly defined resource boundaries. This research presents a challenge to CPR and SES research: how do we determine the efficacy of conclusions drawn about successes and failures of management when boundaries drawn may systematically exclude some users and ignore dimensions of power altogether?

We also found a lack of truly long-term studies showing trends over time (but see De Moor et al. 2016). Thus, SES and CPR research cannot adequately assess intergenerational aspects of success such as justice or equity in access (Gibson 2006), long-term tradeoffs between use and conservation (Klein et al. 2013) or whether institutional path dependencies set limitations on potential social-ecological outcomes (Mahoney 2000; Tekwa et al. 2019). Further, it is important to consider the implications of examining case studies at one moment in time to draw generalizable conclusions about success (Barnett et al. 2016). As these cases are used in synthesis studies, they often lose their historical context and may be treated as temporally invariant, when in reality, outcomes deemed successful or unsuccessful are in flux and are context-specific. These challenges highlight the need to develop trans-disciplinarity, and to examine the role of variables and lessstudied processes in determining successful outcomes.

\subsection{Multidimensionality}

Our second research theme addressed the dimensionality of success measures. We found an emphasis on single measures of success, most often measures of ecosystem conditions or sustainable resource use. While SESs are inherently complex, the simplification of outcomes is a common feature of the success discourse. 
Numerous studies looked at just a single metric of success, in order to address specific hypotheses. The challenges arise in understanding why that metric is being measured as a success indicator (i.e., the transparency issue), and how these data and conclusions are used to inform generalizations about success despite difficulties for comparison across cases due to methodological heterogeneity (i.e., theory building and external validity).

Logistic regressions revealed some characteristics that corresponded to the multidimensionality and uni-dimensionality of studies. The multidimensionality of irrigation success measures may be due to the often-stated challenge of maintaining the provisioning capacity of irrigation infrastructure and water abundance, while also addressing inequalities between head-enders, who often have the capacity to use more irrigation water than tail-enders (Ostrom and Gardner 1993; Baland and Platteau 1999). Correlative studies often examine the effects of independent variables on a target outcome, and thus often consider fewer dimensions of success. Gutierrez et al. (2011), however, aggregated social, economic, and ecological binary outcomes to develop a multidimensional success score with a minimum of zero and maximum of eight. Their resulting analysis did not examine if and how variables such as social cohesion and leadership influence social, economic, and ecological success variables differently. Grassland and rangeland studies often focus on the maintenance of ecosystem variables and biodiversity (Torralba et al. 2016; Robinson et al. 2014; Porter-Bolland et al. 2011), though Howe et al. (2011) explicitly examined tradeoffs and synergies between ecological and socio-economic outcomes. Synthesis studies examining state property systems, such as protected areas, were more likely to consider success as unidimensional. One exception is a meta-analysis conducted by Maliao et al. (2009). This study compared eight indicators encompassing five dimensions of success before and after the implementation of community-based coastal resource management programs, and found mixed success across indicators. These exceptions to unidimensional analyses of success in CPRs and SESs demonstrate that interventions may be effective in one dimension, but have negative or different impacts on others.

While tradeoffs did not contribute to our logistic regression model, all five tradeoff studies considered at least two dimensions of success. These studies provide examples of how to examine the tradeoffs and synergies between livelihoods, sustainability, and equity (Agrawal and Benson 2011), the relative strengths and weaknesses of various typologies of international seafood trade arrangements (Crona et al. 2016), and the potential for projects that incorporate capacity-building and participation in governance to generate synergies among social and ecological outcomes (Brooks et al. 2012; Persha et al. 2011). These findings suggest that although tradeoffs are rarely explicitly examined, they can contribute to more holistic analyses of multidimensional outcomes in synthesis studies.

\subsection{Problem orientations}

Although we found corresponding dimensions of success and problem orientations, we did not find a strong association between descriptions of the overall problem to address and dimensions of success. This suggests that the normative foundations of defining success are not explicitly defined in the framing of journal articles, but implicitly determined by choice of success indicators, or the limitations of available data. Success measures often cannot adequately address the full suite of problems recognized in synthesis research. Our analysis suggests that future research could expand on our current understanding of CPR and SES governance and address problems by developing and testing measures of successful process, such as participation, inclusion in decision-making, and indicators for good governance or management practices. These processes constitute intermediate steps within a causal chain influencing social, ecological, and economic outcomes, trade-offs, and synergies. As we note above, the relationship between private and collective property rights and social group dynamics also play a role in this process by determining who participates in natural resource exploitation and management. Further, socio-economic outcomes are frequently stated as a motivating challenge in synthesis studies, but socio-economic indicators should also be included when assessing outcomes.

Providing a thorough account of the normative foundations to SES and CPR synthesis studies is beyond the scope of this study. Other factors may influence the lack of association between problem orientations and definitions of success, and biases in defining success, such as data availability, challenges when operationalizing and testing dimensions of power, participation, and inclusion, and missing or unavailable data in synthesis studies that review primary literature studies. However, our data indicates that CPR and SES synthesis studies often place the most value on maintaining ecological conditions and reducing the use of natural resources, perhaps unsurprisingly given the theoretical roots of CPR and SES studies. However, our review demonstrates that by expanding our focus on the political processes of natural resource management, the socio-economic impacts on communities, and the conditions that generate tradeoffs and synergies, 
we may develop more holistic examinations of success to improve the conditions of natural resources, livelihoods and equity, and governance arrangements.

\subsection{Critical discussion on collective action for evaluating success}

Measuring success in the CPR and SES literature reflects a broad trend in many fields studying natural resource governance, where finding joint evaluative criteria and definitions as well as making data comparable through increased accessibility and methodological transparency poses significant challenges. If developing robust theories of commons and social-ecological systems governance research is a shared goal and high priority, making generalizable claims about success needs to be well grounded in comparable empirical data. However, Conley and Moote (2003 p. 376) remind us that "whatever form an evaluation takes, researchers must acknowledge that evaluation is normative, and inevitably political...", and thus "... the criteria, weightings, and methods used must be made clear if evaluations are to be fairly compared to each other." The problem is not only due to diverse ways to measure success and its normative nature, but rather trying to make generalized theoretical claims about what success entails with a wide diversity of definitions and a large body of data that is highly heterogeneous and not directly comparable. The vagueness of the term 'success' is both an asset and a limitation in advancing cumulative knowledge about successful SES and CPR governance - an asset because it facilitates dialogue across specific disciplinary lenses, but a limitation because the precise meanings of 'success' in specific disciplines and studies often becomes blurred, which limits the precise accumulation of knowledge about successful SES and CPR governance. Thus, we need to use more specific definitions of success and evaluative criteria (Gibson 2006; Partelow et al. 2019). Much of this difficulty stems from the need to develop methodologies to better structure data comparison, particularly with the use of qualitative data collection and analysis methods, and the combination of qualitative and quantitative methods.

One major challenge for assessing success is data comparability, which stems partly from a collective action problem. Research on knowledge commons suggests that the provision of knowledge is a public good, and thus producing knowledge within science itself represents the structure of a provisioning collective action problem, similar to those observed in natural resource systems. There are few incentives for researchers (with individual interests) to generate and use data collection and analysis techniques that are broadly comparable (the group interest) (Hess and Ostrom 2003; Poteete et al. 2010; Fisher and Fortmann 2010). Methodological novelty in case study research is often rewarded and incentivized in top journals. This leads to new combinations of methods, variables and indicators in a way that will give individual research the best contextual understanding of a case study (higher internal validity). It is also difficult to replicate published research because there are limited incentives to share data or improve methodological transparency in the social sciences (Moravcsik 2014; Rowhani-Farid et al. 2017). Even using common frameworks such as Ostrom's design principles (Ostrom 1990) or the SES framework (Ostrom 2009) across cases does not preclude heterogeneous data collection and analysis methodologies, which makes findings from these studies difficult to compare, requiring secondary coding or analysis that further abstracts from their original meaning (Cox et al. 2010; Thiel et al. 2015; Oberlack et al. 2016; Ratajczyk et al. 2016; Partelow et al. 2018).

Poteete et al. (2010) outline a research program for advancing CPR and SES research through the integration of different methodologies (i.e., experimental with observational; qualitative with quantitative) to advance the field. The core aim of many frameworks, such as Ostrom's SES framework, is to assist data comparability across cases during the research process by providing a tool for researchers to design research questions, data collection and analysis methods using common variables. CPR and SES researchers have developed databases to solve the problem of data comparability post-hoc, by providing structured coding and data entry procedures, retrofitting existing data into data structures that better facilitate meta-analysis. However, substantial progress is lacking, which can largely be attributed to a lack of joint individual incentives and current methodological barriers. For instance, while the SES framework provides some 50 second-tier variables to characterize resource systems and units, governance systems and actors, contexts and related ecosystems, it is vague in terms of operationalizing 'social performance' and 'ecological performance', i.e., the precise metrics of success. Further, there remains space for elaboration on these frameworks, as demonstrated by Clement's (2010) recommendations for expanding on the SES framework by including analyses of discourses, political and cultural factors, and adopting a multi-level analysis of power dynamics. These challenges add to the complexity of developing generalizable theory, and bring into question whether such a goal is attainable. Despite these challenges, we contend that methodological pluralism, combining methodological approaches such as grounded theory, synthesis studies, experiments, and in-depth case studies can improve the process of generating, refining, testing, and revisiting theory, and ultimately better inform CPR and SES management practices. 


\subsection{Methodologies for examining multiple dimensions of success}

As mentioned in section 1.1, the challenge of addressing success in all its complexity while building meaningful theory is not exclusive or necessarily linked to large-N analyses. Some of the reviewed studies indeed demonstrated interesting and innovative methods for explaining success and failure in CPR and SES governance. Most of these studies were ultimately excluded from the above analysis but are discussed qualitatively. Crona et al. (2015) and Srinivasan et al. (2012) approached the evaluation of interactions and outcomes using a syndromes approach. Since social-ecological change is multi-faceted, bringing together multiple processes, flows, and factors co-occurring and operating at different scales and affecting different sectors is valuable. Thus, instead of analyzing social-ecological change in terms of a limited number of predefined "good" or "bad" outcomes, an analysis of syndromes enables researchers to identify the processes, characteristics, trade-offs, and synergies that co-occur with institutional and infrastructural arrangements in different contexts (see also Schellnhuber et al. 1997; Lüdeke et al. 2004; Manuel-Navarrete et al. 2007). These studies make a compelling case for wider usage of analyses of syndromes for understanding complex systems such as CPRs and SESs. Similar approaches are associated with archetype analyses in sustainability research (Eisenack et al. 2006; Sietz et al. 2012; Vaclavik et al. 2013; Oberlack et al. 2016; Eisenack et al. 2019; Oberlack et al. 2019), which identify building blocks of causal interactions beyond the focus on problematic, 'clinical' symptoms typically associated with syndromes (UNEP 2007). Such analyses, however, are most suitable for analysis of an intermediate number of case studies, between in-depth case study research and large-N studies.

Leslie et al. (2015) operationalized Ostrom's (2007) diagnostic SES framework using a combination of mapping to determine SES regions as a unit of analysis and an examination of the relationships between SES variables. They developed 13 indicators encompassing dimensions of resource units, resource system, governance system, and actors. Each variable was quantified and normalized based on their expected relationship to sustainability. Leslie et al. (2015) demonstrate an approach that can integrate qualitative and quantitative data to examine the sustainability of spatially differentiated regions, and to test hypotheses on the interrelationships between SES variables. Further, based on their analysis, they conclude that there are diverse pathways to sustainability facilitated by various combinations of social and ecological factors. Similar to a syndromes approach, this operationalization avoids overemphasizing a limited number of outcomes, and requires in-depth analysis, which may not be suitable for large-N studies. Lastly, Leslie et al. (2015) develop variable scores that abstract from and pre-define relationships between aspects of an SES and sustainability outcomes.

We found some studies that include resilience, adaptation, and the long-term endurance of a governance system as a dimension of success. These studies often rely on a researcher's qualitative assessment of longevity. De Moor et al. (2016) provide a unique methodology for analyzing the success of case studies in terms of longevity. They examined archival records of regulations applied to Dutch, English, and Spanish CPRs spanning as many as 751 years, the link between longevity and commoner participation, sanctioning mechanisms, and operational rules. They suggest that their approach is limited, since archives will only account for formalized rules and not all rules-in-use, and since longevity may not co-occur with other dimensions of success, such as socio-economic benefits, or evenness of power relations. However, they argue that these challenges can be addressed by first reading formal institutional changes as indicators of the evolution of perceived optimal CPR use, and then by combining attention to participation, environmental sustainability, and the reproduction of communities involved. De Moor et al. (2016) demonstrate a novel and innovative strategy to improve our understanding of institutional adaptation and longevity that warrants greater attention among CPR and SES scholars.

\subsection{Four recommendations for future success research}

As a conclusion to the findings and discussion of this research above, we provide four recommendations for analyzing dimensions of success in CPR or SES governance:

(1) Conceptual and Methodological Rigor and Transparency. Our analysis demonstrates that success definitions correspond with constitutional, collective choice, and operational levels of analysis, and behavioral, appropriation, and demand-side provisioning dilemmas. However, few studies explicitly stated these conditions and the social groups to whom success would apply. In order to generate robust theory, the scope and validity of research findings needs to be assessed [by others] accurately (Magliocca et al. 2018). Further, the degree to which this secondary data interpretation and coding is accurate depends on the ability to understand what, how and when data was collected and for what analytical purpose. Methodological rigor should be enhanced by investing more in common, 
well-validated research instruments to operationalize outcome variables in CPR and SES research. To further promote methodological transparency and internal and external validity of study results, studies should include metadata for synthesiss studies.

(2) Iterative and Complementary Analysis. We agree with recommendations for methodological pluralism (Poteete et al. 2012). Further, we recommend increased innovative and constructive integration of qualitative and quantitative methods, as well as inductive and iterative analyses that seek out and examine the gaps, inconsistencies, outliers, and counterfactuals inevitably left by synthesis analyses. For example, Baggio et al. (2016) found configurations of design principles that influenced outcomes in different infrastructural contexts. These results were further supported by and expanded on by a qualitative examination of changing contextual conditions (Barnett et al. 2016). Replication studies and iterations that examine previously defined successes from a multi-dimensional trade-off perspective would expand on and add complexity to CPR and SES governance findings.

(3) Assess Success as Multidimensional The current reliance on singular dependent variables and simple unidirectional models limits our ability to understand the dynamic and contingent nature of success. Studies most often measured success in terms of demand-side provisioning. This leads to many questions, such as, did management practices improve conditions? Did improved conditions negatively or positively impact livelihoods? Future research can place greater emphasis on multiple tradeoffs and the interactions between multiple dimensions of success to contribute to our understanding of SES and CPR as complex, multi-dimensional, and interactive systems.

(4) Integrate Critical Approaches. Social heterogeneity has important implications for SES and CPR management, and some studies have begun to examine the intersections between, for example, sustainability, resilience, justice, equity and socio-cultural diversity measures such as gender and power. Elements of these critical approaches are already present in the literature reviewed. We recommend efforts to increase the frequency of these approaches, and to further integrate with additional critical social science perspectives. Above, we highlight various studies that integrate critical theory concepts to examine CPR and SES management and success, whether adopting inductive or deductive analyses, or large-N or alternative methods. Additional research can further explore how and where various critical approaches can apply to a wide array of CPR and SES studies, particularly the role of interdisciplinarity and transdisciplinarity.

\section{Additional Files}

The additional files for this article can be found as follows:

- Appendices. Defining success in the commons: addressing problem orientations, multidimensionality, norms, and tradeoffs. DOI: https://doi.org/10.5334/ijc.994.s1

- Supplementary data. Data collected and used for the study. DOI: https://doi.org/10.5334/ijc.994.s2

\section{Acknowledgements}

We are grateful to the National Social-Ecological Synthesis Center (SESYNC) in the United States for a supporting grant funding the workshop that led to this work. Thank you to Miguel Laborda-Peman for contributing to the data collection and analysis, and to Edella Schlager and Marty Anderies for recommendations during the project design. We are grateful to the Leibniz Centre for Tropical Marine Research in Germany and Achim Schlüter for making funds available to publish this article open access.

\section{Competing Interests}

One of the co-authors of this article, Sergio Villamayor-Tomas, is a co-editor-in-chief of this journal.

\section{References}

Abson, D. J., H. von Wehrden, S. Baumgärtner, J. Fischer, J. Hanspach, W. Härdtle, H. Heinrichs, A. M. Klein, D. J. Lang, P. Martens, and D. Walmsley. 2014. "Ecosystem services as a boundary object for sustainability." Ecological Economics 103: 29-37. DOI: https://doi.org/10.1016/j.ecolecon.2014.04.012

Agrawal, A. 2005. Environmentality: technologies of government and the making of subjects. Durham, NC: Duke University Press Books. DOI: https://doi.org/10.2307/j.ctv11sn32g

Agrawal, A., and C. S. Benson. 2011. "Common property theory and resource governance institutions: strengthening explanations of multiple outcomes." Environmental Conservation 38(2): 199-210. DOI: https://doi.org/10.1017/S0376892910000925 
Anderies, J. M., and M. A. Janssen. 2016. Sustaining the Commons 2.0. Arizona State University Press. DOI: https://doi.org/10.1017/CBO9781107415324.004

Baggio, J., A. Barnett, I. Perez-Ibarra, U. Brady, E. Ratajczyk, N. Rollins, C. Rubiños, H. Shin, D. Yu, R. Aggarwal, J. Anderies, and M. Janssen. 2016. "Explaining success and failure in the commons: the configural nature of Ostrom's institutional design principles." International Journal of the Commons 10(2): 417-439. DOI: https://doi.org/10.18352/ijc.634

Baldwin, A. 2017. "Resilience and race, or climate change and the uninsurable migrant: towards an anthroporacial reading of 'race." Resilience 5(2): 129-143. DOI: https://doi.org/10.1080/21693293.20 16.1241473

Baland, J.-M., and J.-P. Platteau. 1999. "The Ambiguous Impact of Inequality on Local Resource Management." World Development 27(5): 773-788. DOI: https://doi.org/10.1016/S0305750X(99)00026-1

Barnett, A., J. Baggio, H. Shin, D. Yu, I. Perez-Ibarra, C. Rubinos, U. Brady, E. Ratajczyk, N. Rollins, R. Aggarwal, J. Anderies, and M. Janssen. 2016. "An iterative approach to case study analysis: insights from qualitative analysis of quantitative inconsistencies." International Journal of the Commons 10(2): 467-494. DOI: https://doi.org/10.18352/ijc.632

Barnett, A. J., and H. C. Eakin. 2015. "“We and us, not I and me": Justice, social capital, and household vulnerability in a Nova Scotia fishery." Applied Geography 59: 107-116. DOI: https://doi.org/10.1016/j. apgeog.2014.11.005

Barnett, A. J., R. A. Messenger, and M. G. Wiber. 2017. "Enacting and contesting neoliberalism in fisheries: The tragedy of commodifying lobster access rights in Southwest Nova Scotia." Marine Policy 80: 60-68. DOI: https://doi.org/10.1016/j.marpol.2016.03.002

Boonstra, W. J. 2016. "Conceptualizing power to study social-ecological interactions." Ecology and Society 21(1): 21. DOI: https://doi.org/10.5751/ES-07966-210121

Brewer, J. F. 2012. "Don't Fence Me In: Boundaries, Policy, and Deliberation in Maine's Lobster Commons." Annals of the Association of American Geographers 102(2): 383-402. DOI: https://doi.org/10.1080/000 45608.2011.641889

Brooks, J. S., K. A. Waylen, and M. B. Mulder. 2012. "How national context, project design, and local community characteristics influence success in community-based conservation projects." Proceedings of the National Academy of Sciences of the United States of America 109(52): 21265-21270. DOI: https://doi. org/10.1073/pnas.1207141110

Callon, M., Rip, A., and Law, J. (eds.). 1986. Mapping the Dynamics of Science and Technology: Sociology of Science in the Real World. London: Macmillan Press. DOI: https://doi.org/10.1007/978-1-349-07408-2

Casse, T., and A. Milhøj. 2011. "Community Forestry and Forest Conservation: Friends or Strangers?: Local Forest Management and Forest Conservation: Friends or Strangers?" Environmental Policy and Governance 21(2): 83-98. DOI: https://doi.org/10.1002/eet.566

Cinner, J. E., C. Huchery, M. A. MacNeil, N. A. J. Graham, T. R. McClanahan, J. Maina, E. Maire, J. N. Kittinger, C. C. Hicks, C. Mora, E. H. Allison, S. D'Agata, A. Hoey, D. A. Feary, L. Crowder, I. D. Williams, M. Kulbicki, L. Vigliola, L. Wantiez, G. Edgar, R. D. Stuart-Smith, S. A. Sandin, A. L. Green, M. J. Hardt, M. Beger, A. Friedlander, S. J. Campbell, K. E. Holmes, S. K. Wilson, E. Brokovich, A. J. Brooks, J. J. Cruz-Motta, D. J. Booth, P. Chabanet, C. Gough, M. Tupper, S. C. A. Ferse, U. R. Sumaila, and D. Mouillot. 2016. "Bright spots among the world's coral reefs." Nature 535(7612): 416-419. DOI: https://doi.org/10.1038/ nature 18607

Clement, F. 2010. "Analysing decentralised natural resource governance: proposition for a "politicised" institutional analysis and development framework." Policy Sciences 43(2): 129-156. DOI: https://doi. org/10.1007/s11077-009-9100-8

Conley, A., and M. A. Moote. 2003. "Evaluating Collaborative Natural ResourceManagement." Society \& Natural Resources 16(5): 371-386. DOI: https://doi.org/10.1080/08941920309181

Costello, C., S. D. Gaines, and J. Lynham. 2008. "Can catch shares prevent fisheries collapse?" Science 321(5896): 1678-1681. DOI: https://doi.org/10.1126/science.1159478

Cox, M., G. Arnold, and S. V. Tomás. 2010. "A review of design principles for community-based natural resource management." Ecology and Society 15(4): 38. http://www.ecologyandsociety.org/vol15/iss4/ art38/. DOI: https://doi.org/10.5751/ES-03704-150438

Crona, B. I., T. Van Holt, M. Petersson, T. M. Daw, and E. Buchary. 2015. "Using social-ecological syndromes to understand impacts of international seafood trade on small-scale fisheries." Global Environmental Change 35: 162-175. DOI: https://doi.org/10.1016/j.gloenvcha.2015.07.006 
Crona, B. I., X. Basurto, D. Squires, S. Gelcich, T. M. Daw, A. Khan, E. Havice, V. Chomo, M. Troell, E. A. Buchary, and E. H. Allison. 2016. "Towards a typology of interactions between small-scale fisheries and global seafood trade." Marine Policy 65: 1-10. DOI: https://doi.org/10.1016/j.marpol.2015.11.016

De Lara, J. 2018. Inland Shift: Race, Space, and Capital in Southern California. Univ of California Press. DOI: https://doi.org/10.1525/california/9780520289581.001.0001

De Moor, T., M. Laborda-Pemán, J. M. Lana-Berasain, R. Van Weeren, and A. Winchester. 2016. "Ruling the Commons. Introducing a new methodology for the analysis of historical commons." International Journal of the Commons 10(2): 529. DOI: https://doi.org/10.18352/ijc.760

Edgar, G. J., R. D. Stuart-Smith, T. J. Willis, S. Kininmonth, S. C. Baker, S. Banks, N. S. Barrett, M. A. Becerro, A. T. F. Bernard, J. Berkhout, C. D. Buxton, S. J. Campbell, A. T. Cooper, M. Davey, S. C. Edgar, G. Försterra, D. E. Galván, A. J. Irigoyen, D. J. Kushner, R. Moura, P. E. Parnell, N. T. Shears, G. Soler, E. M. A. Strain, and R. J. Thomson. 2014. "Global conservation outcomes depend on marine protected areas with five key features." Nature 506(7487): 216-220. DOI: https://doi.org/10.1038/nature13022

Eisenack, K., M. Lüdeke, and J. Kropp. 2006. "Construction of archetypes as a formal method to analyze social-ecological systems." In Proceedings of the Institutional Dimensions of Global Environmental Change Synthesis Conference, Vol. 6, No. 9, Bali, December 2006.

Epstein, G., A. Bennett, R. Gruby, L. Acton, and M. Nenadovic. 2014. "Studying power with the socialecological system framework." In Understanding society and natural resources: forging new strands of integration across the social sciences, edited by M. J. Manfredo, J. J. Vaske, and E. A. Duke, 111-137. New York: Springer. DOI: https://doi.org/10.1007/978-94-017-8959-2_6

Eriksen, S. H., A. J. Nightingale, and H. Eakin. 2015. "Reframing adaptation: The political nature of climate change adaptation." Global Environmental Change 35: 523-533. DOI: https://doi.org/10.1016/j. gloenvcha.2015.09.014

Fabinyi, M., L. Evans, and S. J. Foale. 2014. "Social-ecological systems, social diversity, and power: insights from anthropology and political ecology." Ecology and Society 19(4). DOI: https://doi.org/10.5751/ ES-07029-190428

Fisher, J. B., and L. Fortmann. 2010. "Governing the data commons: Policy, practice, and the advancement of science." Information \& Management 47(4): 237-245. DOI: https://doi.org/10.1016/j. im.2010.04.001

Fischer, F. 2003. Reframing public policy: Discursive politics and deliberative practices. New York and Oxford: Oxford University Press.

Frey, U. J. 2017. "A synthesis of key factors for sustainability in social-ecological systems." Sustainability Science 12(4): 507-519. DOI: https://doi.org/10.1007/s11625-016-0395-z

Gibson, R. B. 2006. "Sustainability assessment: basic components of a practical approach." Impact Assessment and Project Appraisal 24(3): 170-182. DOI: https://doi.org/10.3152/147154606781765147

Grove, K., S. Cox, and A. Barnett. 2020. "Racializing Resilience: Assemblage, Critique, and Contested Futures in Greater Miami Resilience Planning." Annals of the American Association of Geographers 1-18. DOI: https://doi.org/10.1080/24694452.2020.1715778

Gutiérrez, N. L., R. Hilborn, and O. Defeo. 2011. "Leadership, social capital and incentives promote successful fisheries." Nature 470(7334): 386-389. DOI: https://doi.org/10.1038/nature09689

Hajjar, R., J. A. Oldekop, P. Cronkleton, E. Etue, P. Newton, A. J. M. Russel, J. S. Tjajadi, W. Zhou, and A. Agrawal. 2016. "The data not collected on community forestry: Community-Forestry Data." Conservation Biology 30(6): 1357-1362. DOI: https://doi.org/10.1111/cobi.12732

Hardin, G. 1968. "The Tragedy of the Commons." Science 162(3859): 1243-1248. DOI: https://doi. org/10.1126/science.162.3859.1243

Hartberg, Y., M. Cox, and S. Villamayor-Tomas. 2016. "Supernatural monitoring and sanctioning in community-based resource management." Religion, Brain \& Behavior 6(2): 95-111. DOI: https://doi.org /10.1080/2153599X.2014.959547

Hess, C., and E. Ostrom. 2003. "Ideas, Artifacts, and Facilities: Information as a Common-Pool Resource." Law and Contemporary Problems 66(1/2): 111-145. https://www.jstor.org/stable/20059174

Hirsch Hadorn, G., S. Biber-Klemm, W. Grossenbacher-Mansuy, H. Hoffmann-Riem, D. Joye, C. Pohl, E. Zemp, et al. (eds.). 2008. Handbook of transdisciplinary research, Vol. 10, 978-1. Dordrecht: Springer. DOI: https://doi.org/10.1007/978-1-4020-6699-3

Howe, C., H. Suich, B. Vira, and G. M. Mace. 2014. "Creating win-wins from trade-offs? Ecosystem services for human well-being: A meta-analysis of ecosystem service trade-offs and synergies in the real world." Global Environmental Change 28: 263-275. DOI: https://doi.org/10.1016/j.gloenvcha.2014.07.005 
Ishiyama, N. 2003. "Environmental Justice and American Indian Tribal Sovereignty: Case Study of a LandUse Conflict in Skull Valley, Utah." Antipode 35(1): 119-139. DOI: https://doi.org/10.1111/14678330.00305

Klain, S. C., R. Beveridge, and N. J. Bennett. 2014. "Ecologically sustainable but unjust? Negotiating equity and authority in common-pool marine resource management." Ecology and Society 19(4). DOI: https:// doi.org/10.5751/ES-07123-190452

Klein, C. J., V. J. Tulloch, B. S. Halpern, K. A. Selkoe, M. E. Watts, C. Steinback, A. Scholz, and H. P. Possingham. 2013. "Tradeoffs in marine reserve design: habitat condition, representation, and socioeconomic costs." Conservation Letters 6(5): 324-332. DOI: https://doi.org/10.1111/conl.12005

Leach, M., I. Scoones, and A. Stirling. 2010. Dynamic sustainabilities: technology, environment, social justice. Earthscan, London, UK, and Washington, DC. DOI: https://doi.org/10.4324/9781849775069

Leslie, H. M., X. Basurto, M. Nenadovic, L. Sievanen, K. C. Cavanaugh, J. J. Cota-Nieto, B. E. Erisman, E. Finkbeiner, G. Hinojosa-Arango, M. Moreno-Báez, S. Nagavarapu, S. M. W. Reddy, A. Sánchez-Rodríguez, K. Siegel, J. J. Ulibarria-Valenzuela, A. H. Weaver, and O. Aburto-Oropeza. 2015. "Operationalizing the social-ecological systems framework to assess sustainability." Proceedings of the National Academy of Sciences 112(19): 5979-5984. DOI: https://doi.org/10.1073/pnas.1414640112

Lüdeke, M. K. B., G. Petschel-Held, and H.-J. Schellnhuber. 2004. "Syndromes of Global Change: The First Panoramic View." GAIA - Ecological Perspectives for Science and Society 13(1): 42-49. DOI: https://doi. org/10.14512/gaia.13.1.10

MacNeil, A. M., and J. E. Cinner. 2013. "Hierarchical livelihood outcomes among co-managed fisheries." Global Environmental Change 23(6): 1393-1401. DOI: https://doi.org/10.1016/j.gloenvcha.2013.04.003

Magliocca, N. R., Ellis, E. C., Allington, G. R., De Bremond, A., Dell'Angelo, J., Mertz, O., and Verburg, P. H. 2018. "Closing global knowledge gaps: Producing generalized knowledge from case studies of social-ecological systems." Global environmental change 50: 1-14. DOI: https://doi.org/10.1016/j.gloenvcha.2018.03.003

Mahoney, J. 2000. "Path dependence in historical sociology." Theory and Society 29(4): 507-548. DOI: https://doi.org/10.1023/A:1007113830879

Maliao, R. J., R. S. Pomeroy, and R. G. Turingan. 2009. "Performance of community-based coastal resource management (CBCRM) programs in the Philippines: A meta-analysis." Marine Policy 33(5): 818-825. DOI: https://doi.org/10.1016/j.marpol.2009.03.003

Mansfield, B. 2007. "Property, Markets, and Dispossession: The Western Alaska Community Development Quota as Neoliberalism, Social Justice, Both, and Neither." Antipode 39(3): 479-499. DOI: https://doi. org/10.1111/j.1467-8330.2007.00536.x

Manuel-Navarrete, D., J. J. Gómez, and G. Gallopín. 2007. "Syndromes of sustainability of development for assessing the vulnerability of coupled human-environmental systems. The case of hydrometeorological disasters in Central America and the Caribbean." Global Environmental Change 17(2): 207-217. DOI: https://doi.org/10.1016/j.gloenvcha.2006.07.002

Meinzen-Dick, R., C. Kovarik, and A. R. Quisumbing. 2014. "Gender and Sustainability." Annual Review of Environment and Resources 39(1):29-55. DOI: https://doi.org/10.1146/annurev-environ-101813-013240

Miller, B. W., S. C. Caplow, and P. W. Leslie. 2012. "Feedbacks between Conservation and Social-Ecological Systems: Conservation and Social-Ecological Systems." Conservation Biology 26(2): 218-227. DOI: https:// doi.org/10.1111/j.1523-1739.2012.01823.x

Moravcsik, A. 2014. "Transparency: The Revolution in Qualitative Research." PS: Political Science \& Politics 47(1): 48-53. DOI: https://doi.org/10.1017/S1049096513001789

Moser, S. C., and M. T. Boykoff. 2013. "Climate change and adaptation success: the scope of the challenge." In Successful Adaptation to Climate Change, edited by S. C. Moser, and M. T. Boykoff, 1-33. London: Routeledge. DOI: https://doi.org/10.4324/9780203593882

Mwangi, E., H. Markelova, and R. Meinzen-Dick. 2012. Collective action and property rights for poverty reduction: insights from Africa and Asia. Philadelphia, US: International Food Policy Research Institute. DOI: https://doi.org/10.9783/9780812207873

Nilsson, M., Chisholm, E., Griggs, D., Howden-Chapman, P., McCollum, D., Messerli, P., Neumann, B., Stevance, A.-S., Visbeck, M., and Stafford-Smith, M., 2018. "Mapping interactions between the sustainable development goals: lessons learned and ways forward." Sustainability science 13(6): 1489-1503. DOI: https://doi.org/10.1007/s11625-018-0604-z

Oberlack, C., L. Tejada, P. Messerli, S. Rist, and M. Giger. 2016. "Sustainable livelihoods in the global land rush? Archetypes of livelihood vulnerability and sustainability potentials." Global environmental change 41: 153-171. DOI: https://doi.org/10.1007/s11625-018-0604-z 
Oberlack, C., P. L. Walter, J. Schmerbeck, and B. K. Tiwari. 2015. "Institutions for sustainable forest governance: Robustness, equity, and cross-level interactions in Mawlyngbna, Meghalaya, India." International Journal of the Commons 9(2): 670-697. DOI: https://doi.org/10.18352/ijc.538

Ostrom, E. 1990. Governing the commons: the evolution of institutions for collective action. New York, NY: Cambridge University Press. DOI: https://doi.org/10.1017/CBO9780511807763

Ostrom, E. 2005. Understanding institutional diversity. Princeton, NJ: Princeton University Press.

Ostrom, E. 2007. "A diagnostic approach for going beyond panaceas." Proceedings of the National Academy of Sciences 104(39): 15181-15187. DOI: https://doi.org/10.1073/pnas.0702288104

Ostrom, E. 2009. "A General Framework for Analyzing Sustainability of Social-Ecological Systems." Science 325(5939): 419-422. DOI: https://doi.org/10.1126/science.1172133

Ostrom, E., R. Gardner, and J. Walker. 1994. Rules, games, and common-pool resources. Ann Arbor, MI: University of Michigan Press. DOI: https://doi.org/10.3998/mpub.9739

Ostrom, E., and R. Gardner. 1993. "Coping with Asymmetries in the Commons: Self-Governing Irrigation Systems Can Work." Journal of Economic Perspectives 7(4): 93-112. DOI: https://doi.org/10.1257/ jep.7.4.93

Pagdee, A., Y. Kim, and P. J. Daugherty. 2006. "What Makes Community Forest Management Successful: A Meta-Study From Community Forests Throughout the World." Society \& Natural Resources 19(1): 33-52. DOI: https://doi.org/10.1080/08941920500323260

Partelow, S., D. Abson, A. Schlüter, M. Fernández-Giménez, H. von Wehrden, and N. Collier. 2019. "Privatizing the commons: New approaches need broader evaluative criteria for sustainability." International Journal of the Commons 13(1): 706-747. DOI: https://doi.org/10.18352/ijc.938

Partelow, S., P. Senff, N. Buhari, and A. Schlüter. 2018. "Operationalizing the social-ecological systems framework in pond aquaculture." International Journal of the Commons 12(1): 485-518. DOI: https:// doi.org/10.18352/ijc.834

Partelow, S. 2018. "A review of the social-ecological systems framework: applications, methods, modifications, and challenges." Ecology and Society 23(4): 36. DOI: https://doi.org/10.5751/ES-10594230436

Partelow, S., and K. Winkler. 2016. "Interlinking ecosystem services and Ostrom's framework through orientation in sustainability research." Ecology and Society 21(3). DOI: https://doi.org/10.5751/ ES-08524-210327

Persha, L., A. Agrawal, and A. Chhatre. 2011. "Social and Ecological Synergy: Local Rulemaking, Forest Livelihoods, and Biodiversity Conservation." Science 331(6024): 1606-1608. DOI: https:// doi.org/10.1126/science.1199343

Pinkerton, E., and R. Davis. 2015. "Neoliberalism and the politics of enclosure in North American small-scale fisheries." Marine Policy 61: 303-312. DOI: https://doi.org/10.1016/j.marpol.2015.03.025

Pollnac, R., P. Christie, J. E. Cinner, T. Dalton, T. M. Daw, G. E. Forrester, N. A. J. Graham, and T. R. McClanahan. 2010. "Marine reserves as linked social-ecological systems." Proceedings of the National Academy of Sciences 107(43): 18262-18265. DOI: https://doi.org/10.1073/pnas.0908266107

Poteete, A. R., M. A. Janssen, and E. Ostrom. 2010. Working together: collective action, the commons, and multiple methods in practice. Princeton, NJ, and Oxford, UK: Princeton University Press. DOI: https://doi. org/10.1515/9781400835157

Poteete, A. 2012. "Levels, scales, linkages, and other "multiples" affecting natural resources." International Journal of the Commons 6(2): 134-150. DOI: https://doi.org/10.18352/ijc.318

Pulido, L. 2017. "Geographies of race and ethnicity II: Environmental racism, racial capitalism and state-sanctioned violence." Progress in Human Geography 41(4): 524-533. DOI: https://doi. org/10.1177/0309132516646495

Ratajczyk, E., U. Brady, J. Baggio, A. Barnett, I. Perez-Ibarra, N. Rollins, C. Rubiños, H. Shin, D. Yu, R. Aggarwal, J. Anderies, and M. Janssen. 2016. "Challenges and opportunities in coding the commons: problems, procedures, and potential solutions in large-N comparative case studies." International Journal of the Commons 10(2): 440-466. DOI: https://doi.org/10.18352/ijc.652

Robinson, B. E., M. B. Holland, and L. Naughton-Treves. 2014. "Does secure land tenure save forests? A meta-analysis of the relationship between land tenure and tropical deforestation." Global Environmental Change 29: 281-293. DOI: https://doi.org/10.1016/j.gloenvcha.2013.05.012

Rowhani-Farid, A., M. Allen, and A. G. Barnett. 2017. "What incentives increase data sharing in health and medical research? A systematic review." Research Integrity and Peer Review 2(1): 4. DOI: https://doi. org/10.1186/s41073-017-0028-9 
Schneider, F., A. Kläy, A. B. Zimmermann, T. Buser, M. Ingalls, and P. Messerli. 2019. "How can science support the 2030 Agenda for Sustainable Development? Four tasks to tackle the normative dimension of sustainability." Sustainability Science 1-12. DOI: https://doi.org/10.1007/s11625-019-00675-y

Schellnhuber, H.-J., A. Block, M. Cassel-Gintz, J. Kropp, G. Lammel, W. Lass, R. Lienenkamp, C. Loose, M. K. B. Lüdeke, O. Moldenhauer, G. Petschel-Held, M. Plöchl, and F. Reusswig. 1997. "Syndromes of Global Change." GAIA - Ecological Perspectives for Science and Society 6(1): 18-33. DOI: https://doi. org/10.14512/gaia.6.1.4

Sietz, D., S. E. M. Choque, and M. K. Lüdeke. 2012. "Typical patterns of smallholder vulnerability to weather extremes with regard to food security in the Peruvian Altiplano." Regional Environmental Change 12(3): 489-505. DOI: https://doi.org/10.1007/s10113-011-0246-5

Smith, H., and X. Basurto. 2019. "Defining Small-Scale Fisheries and Examining the Role of Science in Shaping Perceptions of Who and What Counts: A Systematic Review." Frontiers in Marine Science 6. DOI: https:// doi.org/10.3389/fmars.2019.00236

Srinivasan, V., E. F. Lambin, S. M. Gorelick, B. H. Thompson, and S. Rozelle. 2012. "The nature and causes of the global water crisis: Syndromes from a meta-analysis of coupled human-water studies: Nature and causes of the global water crisis." Water Resources Research 48(10): W10516. DOI: https://doi. org/10.1029/2011WR011087

Steins, N. A., and V. M. Edwards. 1999. "Collective action in common-pool resource management: the contribution of a social constructivist perspective to existing theory." Society \& Natural Resources 12(6): 539-557. DOI: https://doi.org/10.1080/089419299279434

Tekwa, E. W., E. P. Fenichel, S. A. Levin, and M. L. Pinsky. 2019. "Path-dependent institutions drive alternative stable states in conservation." Proceedings of the National Academy of Sciences 116(2): 689-694. DOI: https://doi.org/10.1073/pnas.1806852116

Torralba, M., N. Fagerholm, P. J. Burgess, G. Moreno, and T. Plieninger. 2016. "Do European agroforestry systems enhance biodiversity and ecosystem services?" A meta-analysis. Agriculture, Ecosystems \& Environment 230: 150-161. DOI: https://doi.org/10.1016/j.agee.2016.06.002

Thiel, A., M. E. Adamseged, and C. Baake. 2015. "Evaluating an instrument for institutional crafting: How Ostrom's social-ecological systems framework is applied." Environmental Science \& Policy 53: 152-164. DOI: https://doi.org/10.1016/j.envsci.2015.04.020

UNEP. 2007. Global Environmental Outlook 4. United Nations Environment Programme. Valetta, Malta: Progress Press.

Vaclavík, T., S. Lautenbach, T. Kuemmerle, and R. Seppelt. 2013. "Mapping global land system archetypes." Global Environmental Change 23(6): 1637-1647. DOI: https://doi.org/10.1016/j.gloenvcha.2013.09.004

How to cite this article: Barnett, Allain J., Stefan Partelow, Ulrich Frey, Alejandro García-Lozano, Maria del Mar Mancha-Cisneros, Christoph Oberlack, Elicia Ratajczyk, Hillary Smith, Sergio Villamayor-Tomás, and Charlotte K. Whitney. 2020. "Defining Success in the Commons: Addressing Problem Orientations, Multidimensionality, Norms, and Tradeoffs." International Journal of the Commons 14(1): pp. 366-387. DOI: https://doi.org/10.5334/ijc.994

Submitted: 02 August $2019 \quad$ Accepted: 01 May $2020 \quad$ Published: 24 August 2020

Copyright: ( $) 2020$ The Author(s). This is an open-access article distributed under the terms of the Creative Commons Attribution 4.0 International License (CC-BY 4.0), which permits unrestricted use, distribution, and reproduction in any medium, provided the original author and source are credited. See http://creativecommons.org/licenses/by/4.0/.

$\mathrm{u}[\mathrm{u}$ International Journal of the Commons is a peer-reviewed open access journal published by Ubiquity Press. 